GCPMED 2020

Global Challenges and Prospects of the Modern Economic Development

\title{
KEY FACTORS OF ELECTRIC POWER COMPANIES' INVESTMENT ATTRACTIVENESS DURING THE CORONAVIRUS CRISIS
}

\author{
T. V. Tazihina (a), M. A. Karaseva (b), N. A. Popov (c)* \\ *Corresponding author
}

(a) Financial University under the Government of the Russian Federation, Leningradsky Avenue, 49, Moscow, Russia, tazihina@yandex.ru

(b) KPMG, Presnenskaya Embankment, 10, Moscow, Russia, mariakay@yandex.ru

(c) Financial University under the Government of the Russian Federation, Leningradsky Avenue, 49, Moscow, Russia,mr.nikita.popov97@gmail.com

\begin{abstract}
The article discusses the impact of the Coronavirus Sars-CoV-2 pandemic on Russian electric power companies and the factors of their investment attractiveness that can accelerate the industry's recovery from the crisis and form the basis for strategic development in line with global trends. Changes in profitability and volatility of the MOEX industry indices were analyzed. The result of the analysis was the separation of the Russian economy, represented on the stock market, according to the relative reaction to the COVID19 pandemic into 3 groups. The analysis of the stock market since 2015 has shown that market participants while making decisions under the influence of crisis processes are guided by preconditions different from those, used in stable periods. The conclusion was made that investors are poorly receptive to factors which make companies attractive for investment and they have a low ability to make rational decisions during crisis periods in general. As a result, the current problems of electric energy companies in Russia and around the world and promising areas for development were identified, and 11 key factors for the investment attractiveness of such companies were formulated in the context of four aspects of their business activity. The results of the research can be used by electric energy companies to systematize and priorities resource allocation for the most effective crisis management.
\end{abstract}




\section{Introduction}

The crisis caused by new coronavirus Sars-CoV-2 was another serious challenge for the world economy. According to the October forecast of the International Monetary Fund, the world economy is expected to shrink by $4.4 \%$ in 2020, which is worse than the global financial crisis in 2008 (International Monetary Fund, 2020). The COVID-19 pandemic is not the only challenge for the Russian economy today: the issue is aggravated by a significant deterioration of the situation in commodity markets. Sectors of fuel and energy complex, which account for $60 \%$ of Russia's exports and about $25 \%$ of GDP, show the export revenues cut as a reason for lower budget revenues and business activity reducing (Russian Ministry of Energy, 2020).

Electric power companies are also indirectly affected by the deterioration of domestic and foreign markets: a decrease in demand for resources such as oil, gas and metal ores leads to a reduction in production and, therefore, to a proportional decrease in electricity consumption. Combined with the direct impact of restrictive measures to combat the coronavirus, this led to a reduction in electricity consumption of $3.3 \%$ in the first nine months of 2020 compared to the same period in 2019. For comparison: in 2019, the increase in electricity consumption compared to the previous year in Russia as a whole was $0.4 \%$, in $2018-1.5 \%$ (SO UES, 2020). Maintaining the investment attractiveness of companies in the Russian power sector during the COVID-19 pandemic against the background of declining industry revenues and stagnation of the global economy is now the main task for the industry.

\section{Problem Statement}

Electric power industry is a backbone sector of the economy. After the industry reform in 2008 , the power industry turned from a monopoly into a market industry with foreign players, free circulation of shares and competition in the wholesale market. Preservation of electric power companies' investment attractiveness is a necessary condition for further increase of the energy system functioning efficiency, withdrawal of obsolete capacities, implementation of the policy forced to decarbonize the economy. The electric power sector development is also a stimulus for development of related industries, first of all mechanical engineering.

During the crisis caused by COVID-19, energy companies have to solve two main tasks: to ensure uninterrupted operating activity (short-term perspective) and to compensate for the decrease in financial results by searching new factors of investment attractiveness from the existing global trends of the sector development in the strategic perspective. Active measures will prevent capital flow from the power industry to other sectors of the economy and countries.

\section{Research Questions}

The COVID-19 pandemic has changed the traditional order of things and lifestyle that many people are used to: societies around the world have faced social restrictions, a massive shift to distance working and higher unemployment rates, a ban on cross-border and interregional travel, and a significant increase in the role of distance technologies in education. For the electricity sector, the introduction of such restrictions means a change in consumption profiles: with a significant reduction in the burden on industrial 
consumers, the demand for domestic consumption increases, which creates new problems in the financial and technical aspects of energy companies' operations (Elavarasan et al., 2020). The changings could not be ignored by investors and stock markets, from which the first question arises: "How did markets react to the new crisis? Did the electricity sector have investment attractiveness factors that contributed to reducing the impact of the COVID-19 pandemic on the capitalization of companies in the sector?"

The second main issue of this study is related to short-term challenges and emerging trends in the power industry. Currently renewable energy sources are of particular interest. On the one hand, the global RES sector has suffered less than generation from non-renewable sources of energy: coal, gas, oil and nuclear (Werth et al., 2021). On the other hand, some major green energy investment projects have been cut back, and supply chain disruptions have interrupted the implementation of RES projects already under construction around the world, with particular reference to solar power plants, solar panels and other modules manufactured in China and East Asia (Hosseini, 2020). For the development of renewable energy in Russia, there is a risk that the investment portfolios of oil and gas companies investing in renewable energy will shrink due to falling energy prices. It is important to determine what factors may have a positive impact on the investment attractiveness of energy companies in the long term, as well as to identify industry problems, overcoming which is a priority to ensure continuous operating activity.

\section{Purpose of the Study}

Economic development is currently accompanied by the transformation of the energy sector: the use of existing installed capacities efficiency of traditional non-renewable energy, active efforts are being made to reduce greenhouse gas emissions from power generation facilities, and work is underway to reduce the cost of renewable energy facilities construction and operation. The ongoing globalization processes and open capital markets are forcing power companies operating in the Russian market to compete not only with each other, but also with foreign companies and related industries. In the context of the COVID-19 pandemic, it is important for the power industry not to lose its current positions, but also to use all the opportunities of the crisis to develop ahead. For this purpose it seems necessary to solve current problems, which largely determine the possibility of further development of the industry, and to form long-term development strategies taking into account existing and new trends. The purpose of this article is to identify and formalize the investment attractiveness factors of electric power companies, which could potentially have a positive impact on individual companies and the industry as a whole during the coronavirus crisis.

\section{Research Methods}

\subsection{Retrospective analysis}

The new coronavirus has had an impact on all world markets: prices and yields have fallen sharply, and uncertainty has increased. The main events related to COVID-19 virus were in early March 2020. An additional negative factor affecting the Russian economy in the same period of time was the OPEC+ transaction collapse, which led to a $27 \%$ fall in Brent prices (below $\$ 32$ per barrel) (RBC, 2020). The Russian stock market responded with a collapse and corresponding increase in volatility (Figure 1). 


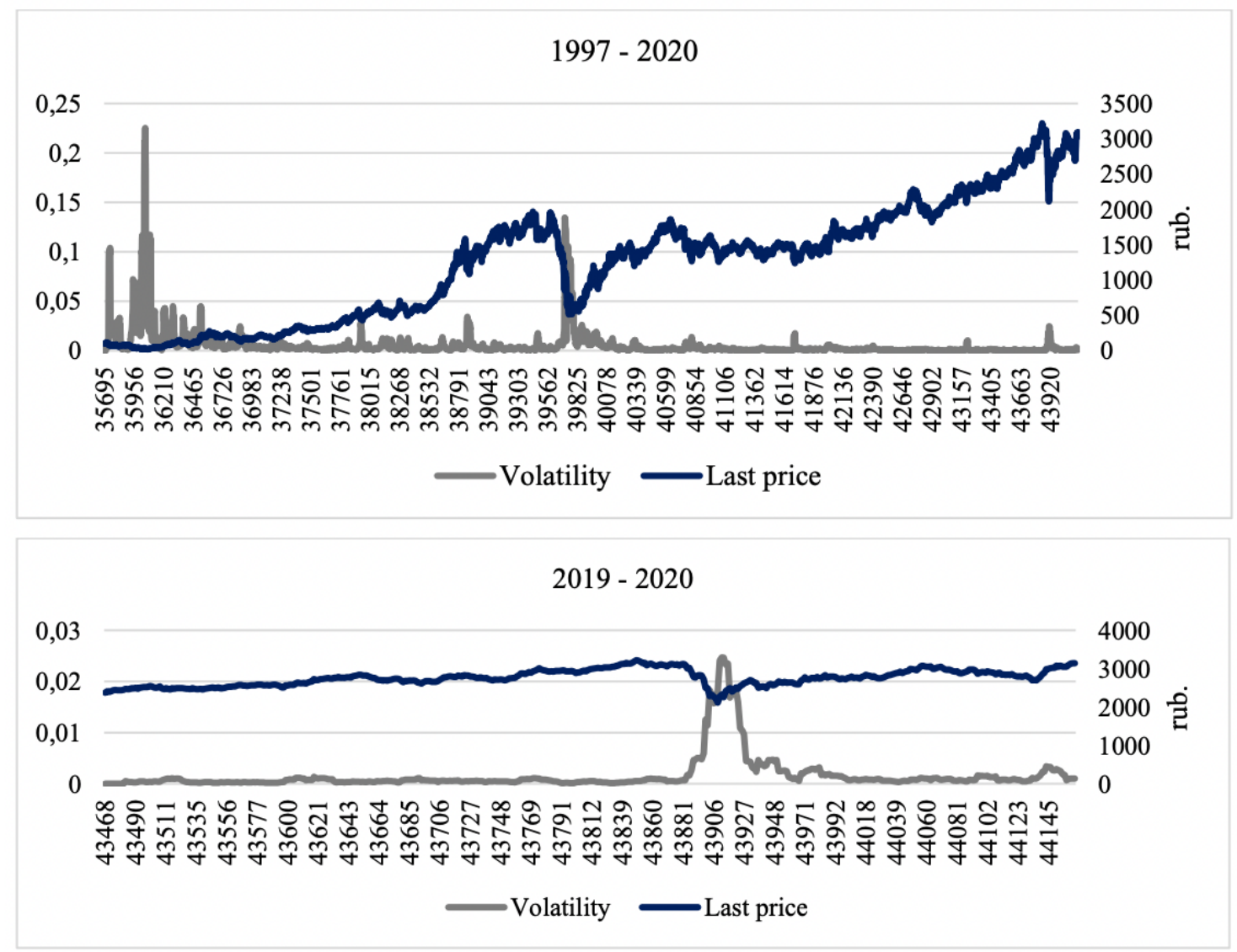

Figure 1. Dynamics of IMOEX Index values and volatility Source: authors.

To analyze the impact of the COVID-19 pandemic and the decline in oil prices on the Russian stock market, the MOEX Index (IMOEX) was selected, which includes 42 of the most liquid shares of the largest and fastest growing Russian issuers as of November 2020. The time period for the analysis, in order to compare with the crisis processes of previous years, was determined from September 22, 1997 (the starting date of the index calculation) to November 24, 2020. Volatility was calculated as the sum of squares of daily yield for 10 days (Baker et al., 2020).

Despite the increase in volatility on the Russian stock market in March this year, the level of price volatility for the period is significantly lower than the impact of the 1998 Russian economic crisis and the 2008 global economic crisis. The dynamics observed are comparable to those of October 2003 (the arrest of Mikhail Khodorkovsky, head of Yukos Oil Company), June 2006 (market correction after long growth) and March 2014 (escalation of political tensions in Ukraine).

In addition, the dynamics of values and volatility of IMOEX since the beginning of 2019 are presented. Volatility peaked at the end of March 2020, but by mid-April the uncertainty had begun to fade. It should be noted that market volatility at the end of November still exceeds pre-crisis levels, as evidenced by the jumps in late April, early June and mid-November.

In order to compare the level of impact of the March 2020 events on companies in the power industry and other sectors of the Russian economy, ten-day volatility charts were constructed for Sectoral Indexes, formed by the Moscow Stock Exchange from Broad Market Index shares (Figure 2). The correlation between the Broad Market Indexes and their codes are shown in Table 1. 
Table 1. Correlation between MOEX indices and codes.

\begin{tabular}{|c|c|}
\hline Index & Index code \\
\hline MOEX Broad Market & MOEXBMI \\
\hline Electric Utilities Indices & MOEXEU \\
\hline Oil \& Gas Indices & MOEXOG \\
\hline Consumer Goods \& Retail Indices & MOEXCN \\
\hline Chemicals Indices & MOEXCH \\
\hline Metals \& Mining Indices & MOEXMM \\
\hline Telecoms Indices & MOEXTL \\
\hline Financials Index & MOEXFN \\
\hline Transport Index & MOEXTN \\
\hline
\end{tabular}

Source: authors.

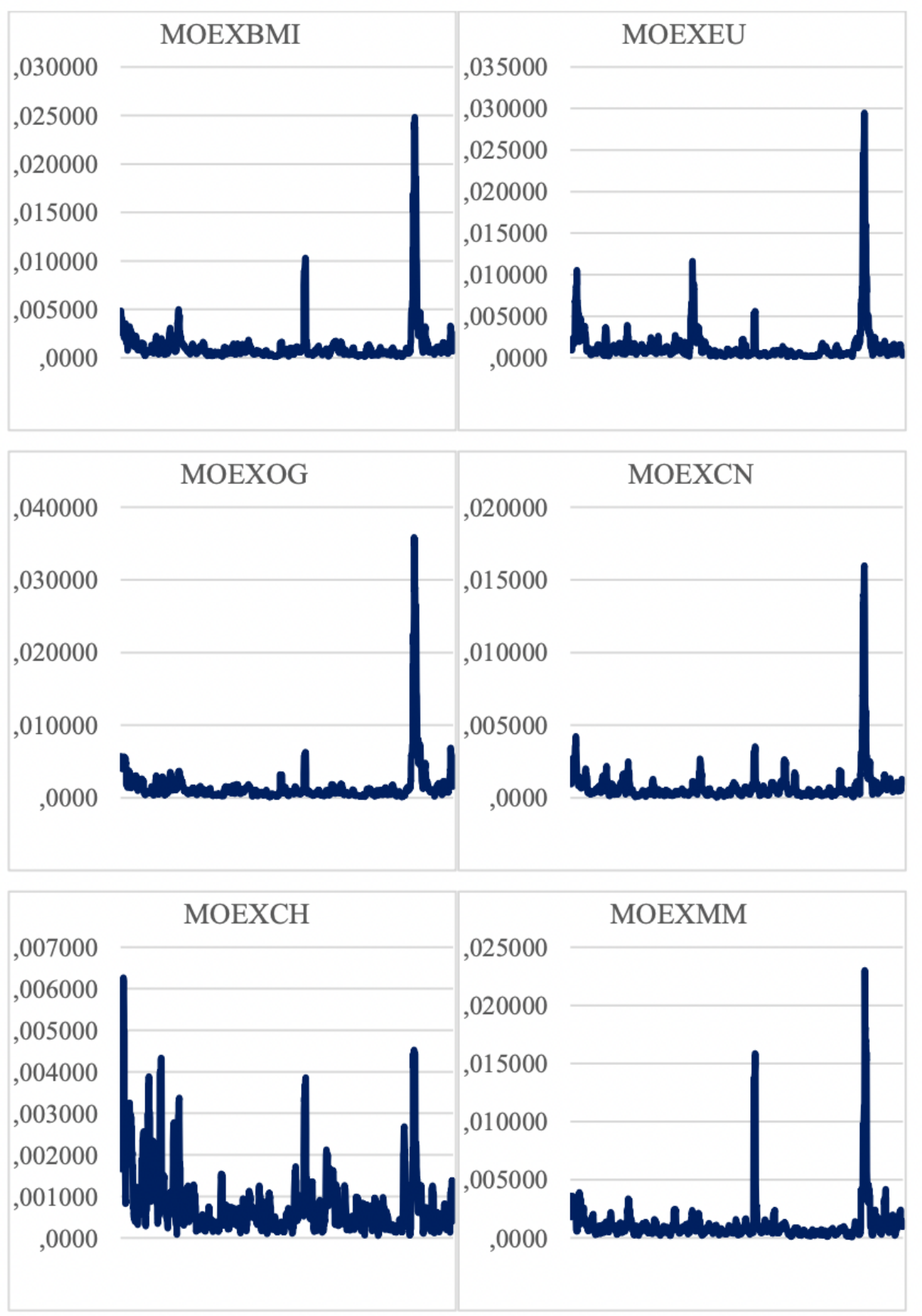




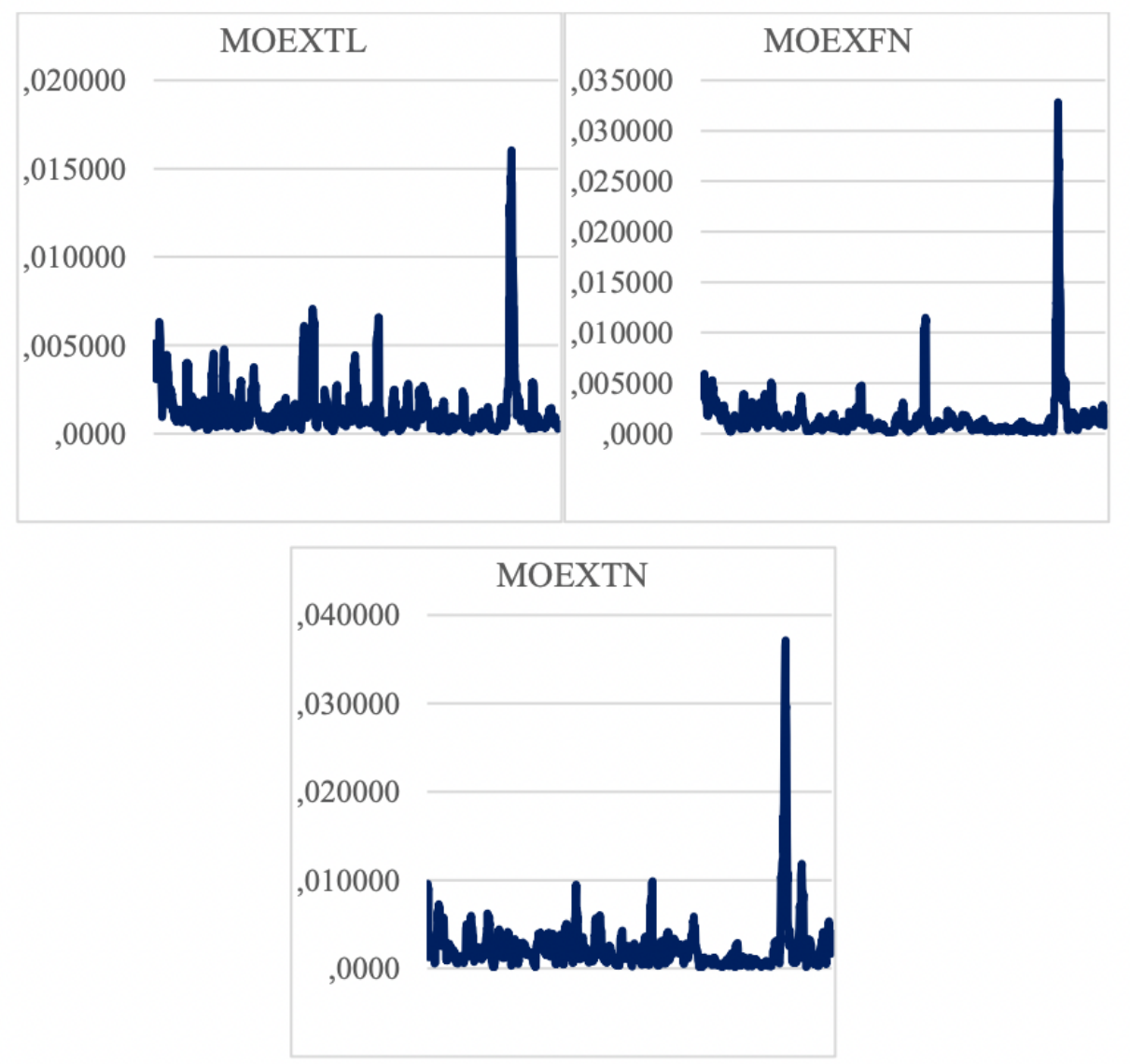

Figure 2. Volatility dynamics of Industry and Broad Market Indices

Source: authors.

The volatility calculation of the Industry Indexes was carried out with help of the method which used to determine the volatility of IMOEX. The MOEX Broad Market Index was chosen as the basis for comparison as it is the basis for the industry indices baskets formation. The time period for the analysis is from the beginning of 2019 to 24 November 2020, as the task of comparing the electricity companies' reaction with other industries reactions and the market as a whole to crisis factors is being solved.

All sectors of the Russian economy represented on the stock market can be divided into 3 groups based on their relative reaction to the COVID-19 pandemic:

- weak reaction: this group includes companies in the chemical and petrochemical industries with a maximum value of volatility of 0.006 ;

- moderate reaction: the maximum value of volatility is in the range from 0.006 to 0.025 . This group includes companies in the consumer and telecommunications sectors;

- strong reaction: the maximum volatility exceeds 0.025 . The group includes companies in the oil and gas, financial and banking, transport and energy sectors.

In order to determine the level of certain industries sensitivity redundancy/insufficiency to the crisis factors of March 2020 with respect to the typical reaction to market dynamics, model values of volatility were determined and compared with the actual values presented above. The model values of index returns were predicted on the basis of a beta coefficient, calculated as a partial division of the covariance between the returns of a single index and the market into the dispersion of market returns. The beta rate was 
calculated for the period from the beginning of 2015 to the end of February 2020. The period chosen took into account the length of the time corridor and the absence of significant fluctuations in the Russian market (see IMOEX volatility analysis). In addition, the maximum daily positive and negative changes in industry indices profitability from the beginning of March to 24 November 2020 were determined (Table 2).

Table 2. Market characteristics of Industry indices and Broad Market Index

\begin{tabular}{|c|c|c|c|c|c|c|c|c|c|}
\hline Indicator & MOEXOG & MOEXCN & $\mathrm{MOEXCH}$ & MOEXMM & MOEXTL & MOEXFN & MOEXTN & $\begin{array}{c}\text { MOEXEU } \\
\text { P }\end{array}$ & $\begin{array}{c}\text { MOEXBM } \\
\text { I }\end{array}$ \\
\hline $\begin{array}{c}\text { Beta } \\
\text { coefficient }\end{array}$ & 1,01 & 0,43 & 0,38 & 0,67 & 0,71 & 0,89 & 0,51 & 0,65 & 1,00 \\
\hline $\begin{array}{c}\text { Volatility } \\
\text { (10D) }\end{array}$ & - & - & - & - & - & - & - & - & 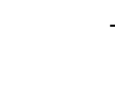 \\
\hline Actual & 0,036 & 0,016 & 0,006 & 0,023 & 0,016 & 0,033 & 0,037 & 0,029 & 0,025 \\
\hline Model & 0,025 & 0,005 & 0,006 & 0,016 & 0,013 & 0,020 & 0,010 & 0,012 & 0,025 \\
\hline $\begin{array}{c}\text { Daily yield } \\
\text { change } \\
\text { (max.) }\end{array}$ & - & - & - & - & - & - & - & - & - \\
\hline Positive & $10,25 \%$ & $4,41 \%$ & $3,51 \%$ & $10,14 \%$ & $5,85 \%$ & $7,47 \%$ & $7,61 \%$ & $7,37 \%$ & $7,72 \%$ \\
\hline Negative & $-11,10 \%$ & $-8,35 \%$ & $-5,28 \%$ & $-7,76 \%$ & $-7,70 \%$ & $-10,03 \%$ & $-9,46 \%$ & $-10,77 \%$ & $-8,28 \%$ \\
\hline
\end{tabular}

Source: authors.

Market participants' valuations of securities, indices and markets in general may differ significantly from fundamentals (Kumar et al., 2020). Hence, the decisions of such participants may deviate instrument quotes from their fundamental value, thereby increasing uncertainty in stock markets. In order to assess this impact on companies in the Russian power industry, a comparison was made between the closing prices and the fundamental value of the power industry companies shares Index (Figure 3). Fair value, calculated by the Bloomberg information and analytical agency, were used as the fundamental estimates.

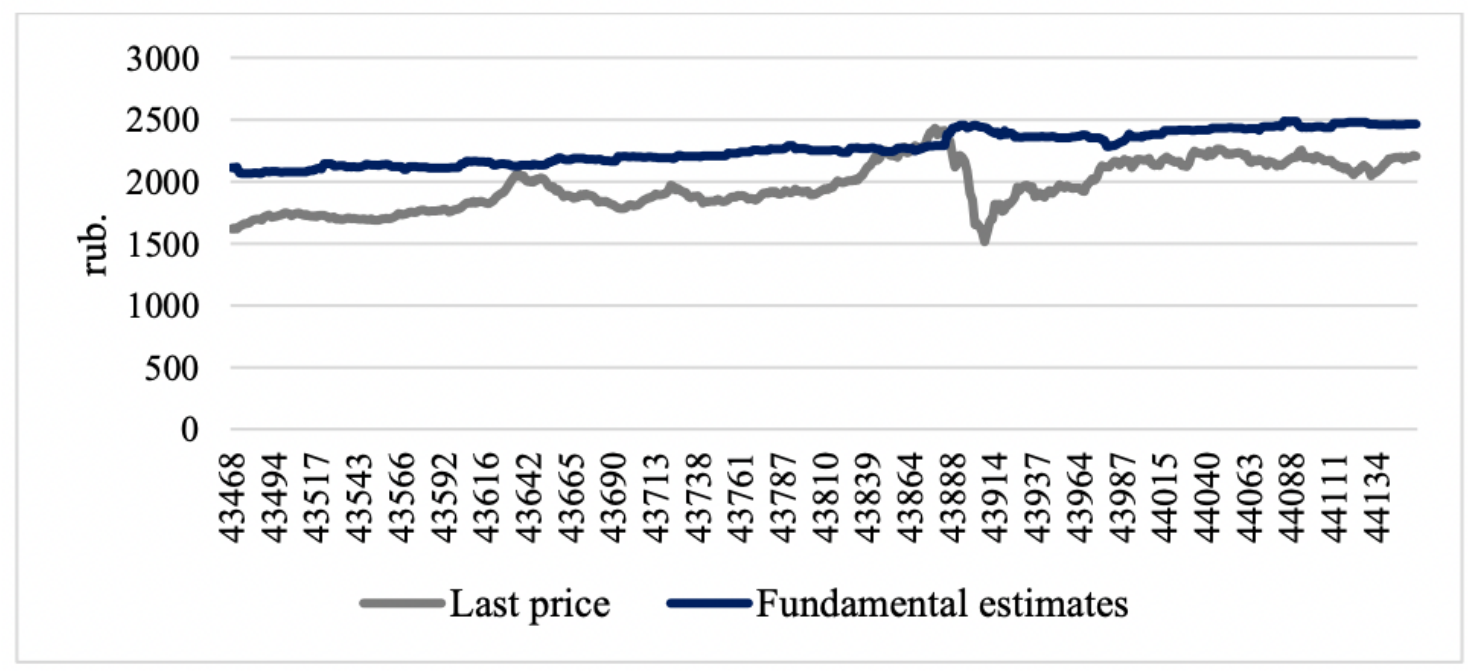

Figure 3. Comparison of fundamental and closing MOEXEU prices Source: authors. 
From the beginning of 2019 to February 2020, the fundamental value of the Russian energy industry companies shares Index exceeded market estimates. The short period of time for MOEXEU index market participants to reevaluate ended with a significant drop in quotations caused by the coronavirus and the absence of OPEC+ agreements. However, there is now an increase in market values for the index, which until the second wave of the COVID-19 pandemic exceeded the peak values of 2019.

\subsection{Summary of scientific publications and empirical research}

A large number of research papers by Russian and foreign authors are devoted to investment attractiveness factors, and they approach the issue from different perspectives. The article (Tazikhina et al., 2021) discusses the investment attractiveness of companies, which is proposed to evaluate from the standpoint of the cost approach. The paper (Junlakarn et al., 2017) systematizes approaches to classifying the investment attractiveness factors of the Association of Southeast Asian Nations countries, which are taken into account in case of making decisions about investments in the country's electricity industry. The macroeconomic factors considered for an individual company can be classified as external factors of investment attractiveness.

Recognizing the importance of traditional investment attractiveness factors and the need to assess them, the authors of this paper have focused on factors and risks associated with the COVID-19 pandemic and its associated trends. Many factors taken under consideration are of a dual nature: on the one hand, they represent risks for energy companies that cannot be ignored; on the other hand, the effectiveness of measures in these areas will serve as an indicator for investors of a company's ability to adapt to crisis conditions, which will increase the individual organization investment attractiveness.

The authors of this paper based on analysis (Energy Centre of the Moscow School of Management SKOLKOVO, 2020; IEA, 2020; PwC, 2020) identified 11 factors of electric power companies investment attractiveness, which are key ones during the COVID-19 pandemic and are necessary for successful operation and development in the foreseeable future. All factors were divided into 4 major blocks: finance and investment, operations, HR and strategic development. The first three groups are related to the functioning of companies during the coronavirus crisis, they provide continuity of operations and lay the foundation for further development opportunities. The Strategic Development Group includes factors in line with global energy trends, which were given new impetus during the COVID-19 pandemic (Table 3).

Table 3. Key factors of electric power companies' investment attractiveness during the coronavirus crisis

\begin{tabular}{ccll}
\hline Group & Code & \multicolumn{1}{c}{ Factor } & \multicolumn{1}{c}{ Source } \\
\hline $\begin{array}{l}\text { Finance and } \\
\text { investments }\end{array}$ & F-1 & $\begin{array}{l}\text { Management of } \\
\text { receivable and } \\
\text { payable } \\
\text { accounts }\end{array}$ & (Energy Centre of the Moscow School of Management \\
& F-2 & $\begin{array}{l}\text { Implementation } \\
\text { of investment } \\
\text { programmes } \\
\text { Expansion of } \\
\text { the content of } \\
\text { annual reports } \\
\text { Creation of } \\
\text { conditions for }\end{array}$ & SKOLKOVO, 2020) \\
& F-3 & (PwC, 2020) \\
Work with & P-1 & \\
personnel & &
\end{tabular}




\begin{tabular}{|c|c|c|c|}
\hline & & $\begin{array}{l}\text { safe personnel } \\
\text { work }\end{array}$ & \\
\hline & P-2 & $\begin{array}{l}\text { Ensuring } \\
\text { business } \\
\text { continuity }\end{array}$ & $\begin{array}{l}\text { (PwC, 2020; Energy Centre of the Moscow School of } \\
\text { Management SKOLKOVO, 2020) }\end{array}$ \\
\hline \multirow[t]{3}{*}{$\begin{array}{l}\text { Operating } \\
\text { activities }\end{array}$} & O-1 & $\begin{array}{l}\text { Establishment } \\
\text { of effective } \\
\text { cooperation } \\
\text { structures }\end{array}$ & $(\mathrm{PwC}, 2020)$ \\
\hline & $\mathrm{O}-2$ & $\begin{array}{l}\text { Information } \\
\text { Security } \\
\text { Management }\end{array}$ & $(\mathrm{PwC}, 2020)$ \\
\hline & $\mathrm{O}-3$ & $\begin{array}{l}\text { Interaction } \\
\text { with suppliers }\end{array}$ & (PwC, 2020; IEA, 2020) \\
\hline \multirow[t]{3}{*}{$\begin{array}{l}\text { Strategic } \\
\text { development }\end{array}$} & S-1 & $\begin{array}{l}\text { Development } \\
\text { of renewable } \\
\text { energy sources }\end{array}$ & (IEA, 2020) \\
\hline & S-2 & $\begin{array}{l}\text { Downsizing of } \\
\text { non-core assets }\end{array}$ & (IEA, 2020) \\
\hline & S-3 & $\begin{array}{l}\text { Digital } \\
\text { transformation }\end{array}$ & $\begin{array}{l}\text { (PwC, 2020; Energy Centre of the Moscow School of } \\
\text { Management SKOLKOVO, 2020) }\end{array}$ \\
\hline
\end{tabular}

Source: authors

Finance and investments:

F-1. The decline in household and business income has led to an increase in non-payments, which may jeopardize the operating and investment activities of electric power companies. Since the instruments of influence on debtors in the case of power companies are limited by the current regulatory field, their actions may be aimed at establishing a permanent dialogue with consumers and regulatory authorities.

F-2. A drop in revenues and an increase in non-payments threaten the implementation of investment programmes. It is necessary to identify, together with government authorities, the critical investment projects, the implementation of which is the most important for the energy system. In addition, it is crucially to prevent the review of projects that are already in developed stages of implementation. This will reduce the possibility of losses for energy companies and their contractors.

F-3. The pandemic has had a significant impact on companies' financial results, added new risk factors and shaken their financial stability. It is crucial to share information with investors on business results, risk factors and measures to respond to them, and plans for further development. This will enable companies to maintain transparency and give investors an understanding of their investment prospects.

Work with personnel:

P-1. Due to the specifics of their business, electricity companies cannot transfer all employees to remote work. In the conditions of a pandemic, it is important to ensure safety for personnel. Measures in this area may consist of providing employees with personal protective equipment, constant monitoring of their health, arrangement of workplaces that reduce the risk of coronavirus infection.

P-2. Given the constant risk of new infections, it is important for companies to establish a personnel management system that will ensure uninterrupted activity. To this end, large repair and maintenance teams can be divided into smaller structures, a personnel reserve has been formed and additional teams have been created to develop operational solutions and respond to emergency situations. 
Operational activities:

O-1. In order to prevent the spread of coronavirus infection and improve the efficiency of operations, agreements may be concluded with other companies in the industry (in terms of resource support) and with government authorities (in terms of information exchange).

O-2. The remote mode of operation increases the vulnerability of companies' information systems. It is advisable to improve information security by conducting additional discussions with personnel, periodic testing of the IT systems against phishing attacks, and the introduction of reliable remote work models.

O-3. Limited transport flows may complicate the supply of spare parts and critical equipment elements. Continuous monitoring of the parts availability and information interaction with suppliers will make it possible to take the necessary measures in a timely manner and prevent failure of power facilities.

Strategic development:

S-1. The overall global trend towards green generation has intensified against the backdrop of the pandemic, despite all the difficulties encountered. Russia is currently lagging behind its western counterparts in this area. The development of renewable energy should become a priority for Russian electric power companies, which will help to avoid an investment attractiveness reduction in the background of foreign companies and significantly reduce operating costs in the future. The development of RES is particularly important for exporting companies, which may face carbon taxation in the EU countries.

S-2. The crisis caused by the COVID-19 pandemic may be a good incentive to reduce non-core assets and optimize administrative costs. Successful implementation of measures in this area will free up additional financial resources and reduce maintenance costs of such assets in the future.

S-3. The digitalization of the electric energy companies' business has now evolved from a means of increasing operational activity to one of the main ways for business survival.

\section{Findings}

The crisis caused by the COVID-19 pandemic has affected the vast majority of Russian economic sectors. Manifestation of this fact was also reflected in the increased volatility and the significant daily decrease in the profitability of industry indices on the Moscow Exchange. The analysis showed that the reaction of market participants to the crisis factors by individual indices had little in common with their assessment of sectors in periods of stability: actual volatility was up to 3.6 times higher than the model values determined on the basis of data for previous periods. It should also be noted that significant daily changes in yields - over $11 \%$ - are characteristic of all the indices under consideration, and their magnitude has little correlation with the historical dynamics of yields in relation to market averages. For the Index of the Russian energy industry companies shares, there is a deviation between market estimates and fundamental values.

All mentioned above testifies to the weak investors receptivity to factors of companies' investment attractiveness and low ability to make rational decisions during crisis periods (Chang et al., 2020). In this regard, it seems appropriate to determine the key factors of electric power companies' investment attractiveness during the crisis based on the problems that have emerged, as well as long-term trends. With 
this approach, it is highly probable that companies will not only be able to survive the crisis due to the concentration of resources in the most important areas, but will also be competitive objects of investment activity to the stage of stabilizing the economic situation. Based on the proposed approach, the authors identified 11 key factors in the investment attractiveness of electric energy companies, which, in their opinion, will help prevent capital outflow from the sector to other industries and countries.

\section{Conclusion}

This study does not claim to be an exhaustive analysis of the electric power companies' investment attractiveness. Answers to the research questions have been provided and the research purpose has been achieved. Identified groups of factors can help electric energy companies identify and systematize the most promising measures for overcoming the crisis. It is important to emphasize once again the need to form strategic plans in line with long-term trends, in addition to solving short-term tasks, despite the need for significant financial resources. Besides, this research may be relevant for all investors who would like to reduce volatility of the value of investment portfolios through the sectoral diversification. Further research in this area may be aimed at quantifying the impact of individual factors on the final value of investment attractiveness. It is also interesting to correlate the identified investment attractiveness factors with the common classifications.

\section{References}

Baker, S. R., Bloom, N., Davis, S. J., Kost, K., Sammon, M., \& Viratyosin, T. (2020). The unprecedented stock market reaction to COVID-19. The Review of Asset Pricing Studies, 10(4), 742-758. https://doi.org/10.1093/rapstu/raaa008

Chang, Ch.-L., McAleer, M., \& Wang, Y.-A. (2020). Herding behaviour in energy stock markets during the Global Financial Crisis, SARS, and ongoing COVID-19. Renewable and Sustainable Energy Reviews, 134, 110349. https://doi.org/10.1016/j.rser.2020.110349

Elavarasan, R. M., Shafiullah, G. M., Raju, K., Mudgal, V., Arif, M. T., Taskin, J., Subramanian, S., Sriraja Balaguru, V. S., Reddy, K. S., \& Subramaniam, U. (2020). COVID-19: Impact analysis and recommendations for power sector operation. Applied Energy, 279, 115739. https://doi.org/10.1016/j.apenergy.2020.115739

Energy Centre of the Moscow School of Management SKOLKOVO (2020). Coronavirus crisis: Impact of COVID-19 on the global and Russian fuel and energy sector. https://energy.skolkovo.ru/downloads/documents/SEneC/Research/SKOLKOVO_EneC_COVID1 9_and_Energy_sector_RU.pdf

Hosseini, S. E. (2020). An outlook on the global development of renewable and sustainable energy at the time of COVID-19. Energy Research \& Social Science, 68, 101633. https://doi.org/10.1016/j.erss.2020.101633

IEA (2020). Global Energy Review 2020. The impacts of the Covid-19 crisis on global energy demand and CO2 emissions. https://webstore.iea.org/global-energy-review-2020

International Monetary Fund (2020). World economic outlook, October 2020: A long and difficult ascent. https://www.imf.org/en/Publications/WEO/Issues/2020/09/30/world-economic-outlook-october2020

Junlakarn, S., Wangjiraniran, W., \& Phadungsri, D. (2017). Opportunities of power generation investment in ASEAN through assessing market attractiveness. Energy Procedia, 142, 2831-2837. https://doi.org/10.1016/j.egypro.2017.12.429 
Kumar, A., Badhani, K. N., Bouri, E., \& Saeed, T. (2020). Herding behavior in the commodity markets of the Asia-Pacific region. Finance Research Letters, 101813. https://doi.org/10.1016/j.frl.2020.101813

PwC (2020). PwC US CFO pulse survey. https://www.pwc.com/us/en/library/covid-19/pwc-covid-19-cfopulse-survey.html

RBC (2020). Oil, ruble, world markets collapses. Main subject. https://www.rbc.ru/economics/09/03/2020/5e65c8d79a79475986e346af

Russian Ministry of Energy (2020). Alexander Novak: "By 2024 we can increase investment in the fuel and energy complex by $50 \% "$ ". https://minenergo.gov.ru/node/13952\#: :text=\%D0\%A1\%D0\%B5\%D0\%B3\%D0\%BE\%D0\%B4 $\% \mathrm{D} 0 \% \mathrm{BD} \% \mathrm{D} 1 \% 8 \mathrm{~F} \% 20 \% \mathrm{D} 0 \% \mathrm{~A} 2 \% \mathrm{D} 0 \% \mathrm{AD} \% \mathrm{D} 0 \% 9 \mathrm{~A} \% 20 \% \mathrm{D} 1 \% 84 \% \mathrm{D} 0 \% \mathrm{BE} \% \mathrm{D} 1 \% 80 \% \mathrm{D} 0 \%$ BC $\%$ D0\%B8\%D1\%80\%D1\%83\%D0\%B5\%D1\%82\%2025\%25\%20\%D0\%92\%D0\%92\%D0\%9F, \%D0\%B2\%20\%D0\%A2\%D0\%AD\%D0\%9A\%20\%2D\%205\%20\%D1\%82\%D1\%80\%D0\%BB\% D0\%BD $\% 20 \% \mathrm{D} 1 \% 80 \% \mathrm{D} 1 \% 83 \% \mathrm{D} 0 \% \mathrm{~B} 1 \% \mathrm{D} 0 \% \mathrm{BB} \% \mathrm{D} 0 \% \mathrm{~B} 5 \% \mathrm{D} 0 \% \mathrm{~B} 9$

SO UES (2020). Press release. Power consumption in UES of Russia in September 2020 decreased by $3.0 \%$ $\begin{array}{llll}\text { compared } & \text { to } & \text { September } & \mathrm{https} / / \mathrm{so}-\end{array}$ ups.ru/index.php?id=press_release_view\&tx_ttnews[tt_news] $=16733 \& \mathrm{cHash}=95 \mathrm{c} 058474 \mathrm{a}$

Tazikhina, T. V., Andrianova, J. V., \& Zinin A. A. (2021). Investment attractiveness of companies: Formation and assessment. In S. I. Ashmarina, J. Horák, J. Vrbka, P. Šuleř (Eds.), Economic Systems in the New Era: Stable Systems in an Unstable World. IES 2020. Lecture Notes in Networks and Systems, 160 (pp. 358-365). Springer. https://doi.org/10.1007/978-3-030-60929-0_46

Werth, A., Gravino, P., \& Prevedello, G. (2021). Impact analysis of COVID-19 responses on energy grid dynamics in Europe. Applied Energy, 281, 116045. https://doi.org/10.1016/j.apenergy.2020.116045 